\title{
KADAR SENG SERUM DAN RASIO MOLAR FITAT:SENG PADA ANAK USIA SEKOLAH DASAR DI PESISIR KOTA SEMARANG
}

\author{
Ulil Albab $^{1}$, Aryu Candra ${ }^{1}$, Ninik Rustanti ${ }^{1}$ \\ ${ }^{1}$ Departemen Ilmu Gizi, Fakultas Kedokteran, Universitas Diponegoro \\ Jln. Prof. H. Soedarto, SH., Semarang, Telp (024) 8453708, Email : gizifk@ undip.ac.id
}

\begin{abstract}
Background: School-age children are at risk of zinc deficiency which can be identified by measuring serum zinc levels. Zinc intake, in particular, strongly affects zinc absorption and consequently alters serum zinc concentration. Phytate is the strongest inhibitor of zinc absorption. The scale of its inhibitory ability can be measured through phytate:zinc molar ratio. This study aimed to describe phytate:zinc molar ratio in school-age children in coastal area of Semarang.

Method: This was a cross-sectional study on 50 samples of children aged 9-12 years chosen by non probability sampling from several elementary schools in Semarang. Observed data include subject characteristics, zinc intake, phytate intake, and serum zinc levels. Participants' intake was assessed using $3 \times 24$ hour food recall and food record, while serum zinc levels were evaluated through Atomic Absorbant Spechtrophotomety (AAS) methods. Data was analyzed by Pearson's test.

Result: The mean serum zinc level was $93,85 \pm 22,99 \mu \mathrm{g} / \mathrm{dl}$, with a phytate:zinc molar ratio of 14,48 $\pm 4,23$. Only $14 \%$ of the subjects had low zinc serum levels, but there was $46 \%$ with low zinc absorption rates according to their molar ratio of phytate:zinc. No significant correlation was detected between phytate:zinc molar ratio and serum zinc levels $(p=0,427)$. Conclusion: Low zinc serum levels was found in 14\% of the subjects while $46 \%$ had low zinc absorption rate. No significant correlation was detected between phytate:zinc molar ratio and serum zinc levels.
\end{abstract}

Key Words: zinc, phytate, molar ratio, coastal are

\section{ABSTRAK}

Latar Belakang: Anak usia sekolah dasar berisiko kekurangan zat gizi seng, untuk mengetahuinya dapat dilakukan pengukuran kadar seng serum. Asupan seng merupakan faktor yang paling berpengaruh pada absorbsi seng yang akan menentukan keadaan kadar seng serum. Fitat merupakan penghambat absorbsi seng yang paling kuat. Tingkat penghambatan oleh fitat dapat diketahui melalui estimasi perhitungan rasio molar fitat:seng. Tujuan penelitian untuk melihat gambaran rasio molar fitat:seng pada anak usia sekolah dasar di Pesisir kota Semarang.

Metode: Merupakan penelitian observasional dengan rancangan cross sectional. Pemilihan subjek menggunakan non probability sampling yang melibatkan 50 anak usia 9-12 tahun yang ditentukan berdasarkan kriteria inklusi di Sekolah Dasar, Kota Semarang. Data yang dikaji meliputi karakteristik subjek, asupan seng, asupan fitat, dan kadar seng serum. Data asupan diperoleh melalui wawancara langsung menggunakan $3 \times 24$ hours food recall dan food record. Kadar seng serum menggunakan metode Atomic Absorption Spechtrophotomety (AAS). Data dianalisis menggunakan uji Pearson.

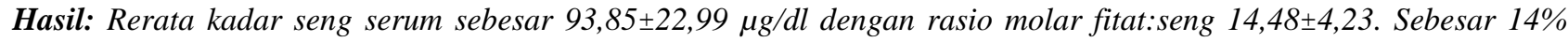
subjek memiliki kadar seng serum rendah dan sebesar $46 \%$ subjek memiliki rasio molar fitat:seng $\geq 15$ yang menunjukkan tingkat absorpsi seng rendah. Tidak terdapat hubungan yang signifikan antara rasio molar fitat:seng dengan kadar seng $\operatorname{serum}(p=0,427)$.

Simpulan: Persentase dari hasil kadar seng serum subjek yang mengalami defisiensi seng sebesar 14\% dan sibjek yang memiliki tingkat absorpsi seng rendah sebesar 46\%. Tidak terdapat hubungan yang signifikan antara rasio molar fitat:seng dengan kadar seng serum

Kata Kunci: Seng, fitat, rasio molar, pesisir

\section{PENDAHULUAN}

Anak usia sekolah dasar merupakan kelompok yang rentan terhadap kekurangan zat gizi mikro, salah satunya adalah seng. Zat gizi seng berperan penting dalam kekebalan tubuh untuk pencegahan infeksi oleh berbagai jenis bakteri patogen ${ }^{1}$. Selain itu juga penting dalam pembelahan dan pematangan sel, serta pertumbuhan. Seng juga bermanfaat dalam perkembangan otak yaitu untuk perkembangan saraf dan fungsi sistem saraf pusat ${ }^{2}$. Berdasarkan penelitian, kekurangan seng pada anak-anak dapat menyebabkan stunting (pendek) ${ }^{3}$.
International Conference of Zinc and Human Health memperkirakan $49 \%$ populasi dunia mempunyai risiko terjadinya defisiensi seng ${ }^{4}$.Wilayah yang memiliki risiko terbesar mengalami defisiensi seng adalah Afrika, Asia Selatan, dan Asia Tenggara ${ }^{5}$. Sebuah penelitian di Iran tahun 2009 mengungkapkan bahwa 28,1\% anak usia 9-11 tahun mengalami defisiensi seng ${ }^{6}$. Berdasarkan data dari Departemen Kesehatan Republik Indonesia Tahun 2006 tentang studi gizi mikro di 10 Provinsi, menemukan prevalensi rata-rata anak-anak kekurangan seng sebesar $36.1 \%{ }^{4}$. 
Prevalensi stunting pada anak usia sekolah dasar (usia 5-12 tahun) adalah 30,7 \% dan di Jawa Tengah sebesar $28 \%{ }^{7}$. Penelitian pada beberapa sekolah di pesisir Semarang menunjukkan terjadinya defisiensi seng sebesar $75 \%$ pada tahun $2015^{8}$.

Salah satu penyebab defisiensi seng adalah karena asupan fitat. Asupan fitat pada laki-laki di pesisir Semarang sejumlah 1073,44 mg dan pada perempuan sejumlah $986,43 \mathrm{mg}^{8}$. Data ini menunjukkan bahwa daerah pesisir selain mengonsumsi hasil perikanan dan jenis laut lainnya, juga mengonsumsi pangan nabati seperti kacangkacangan, sereal, dan sayur-sayuran. Pangan nabati tersebut juga memiliki kandungan fitat didalamnya sehingga meningkatkan risiko terjadinya defisiensi seng.

Status seng di dalam tubuh dapat ditentukan dengan beberapa pengukuran yaitu, pengukuran kadar seng serum, kadar seng eritrosit, leukosit, netrofil, dan kadar seng pada rambut. Namun, diantara kelima pengukuran tersebut, kadar seng serum adalah yang paling sering digunakan ${ }^{9}$. Kadar seng serum dipengaruhi oleh berbagai faktor, diantaranya yaitu dari faktor stres ${ }^{10}$, asupan ${ }^{9}$, suplementasi ${ }^{11}$, dan status gizi ${ }^{12}$. Faktor yang paling berpengaruh adalah asupan makanan. Pada asupan makanan terdapat zat yang dapat meningkatkan dan menghambat kadar seng serum atau absorpsi seng.

Zat gizi yang dapat meningkatkan absorbsi seng adalah protein $^{9}$ yang berperan sebagai salah satu komponen asupan dalam mempengaruhi kecepatan absorpsi dan status dari seng ${ }^{13}$. Berikutnya zat yang dapat menghambat absorpsi seng adalah fitat, tembaga, kalsium, besi. Fitat merupakan penghambat mineral yang kuat, termasuk seng, karena fitat tidak dapat diabsorpsi pada pencernaan manusia, mineral yang terikat pada fitat akan melewati usus tanpa diserap $^{9}$ dan fitat adalah yang paling berpengaruh terhadap absorbsi seng ${ }^{14}$. Tembaga akan mempengaruhi absorpsi seng. Ketika jumlah seng di dalam tubuh berada pada kondisi rendah, maka tembaga dapat menghambat absorbsi seng ${ }^{15}$. Kalsium dapat menghambat seng apabila berada bersamaan dengan fitat ${ }^{15}$. Besi memiliki beberapa tempat absorpsi yang bersamaan dengan absorpsi seng, sehingga apabila besi memiliki jumlah yang lebih besar daripada jumlah seng maka akan menghambat absorpsi seng ${ }^{16}$.

Seng terdapat pada bahan pangan hewani seperti daging ayam, sapi, babi, ikan, seafood, dan telur. Selain itu, juga terdapat pada bahan pangan nabati seperti kacang-kacangan, biji-bijian, dan sereal. Kandungan seng lebih banyak terdapat pada makanan hewani ${ }^{15}$. Berdasarkan rata-rata konsumsi per kapita dalam seminggu, beberapa macam bahan pangan seperti beras, ikan dan udang, daging sapi/kerbau, daging ayam, telur ayam, tempe, dan tahu, semua bahan pangan tersebut mengalami peningkatan ratarata konsumsi dari tahun 2014-2015 ${ }^{17}$. Makanan nabati seperti tempe, tahu, dan beras yang memiliki kandungan seng ini juga memiliki kandungan tinggi fitat yang akan mengganggu absorpsi dari seng. Selain itu, seng merupakan mineral esensial yang paling memberikan efek oleh fitat dibandingkan mineral-mineral lainnya seperti tembaga, nitrat, kobalt, mangan, dan kalsium ${ }^{16}$.

Efek penghambatan fitat pada absorbsi seng membutuhkan estimasi untuk mengetahui seberapa banyak fitat menghambat seng yaitu dengan rasio molar fitat:seng ${ }^{15}$. Rasio ini menggunakan molar karena fitat dan seng di dalam tubuh berperan sebagai zat terlarut di dalam larutan dan molar merupakan cara yang tepat untuk menyatakan komposisi $\operatorname{larutan}^{18}$. Terdapat penelitian pada tikus, yang mengungkapkan bahwa rasio molar fitat:seng merupakan faktor utama dalam mempengaruhi bioavailabilitas dalam mengonsumsi asupan seng ${ }^{14}$. Penelitian tersebut dilakukan dengan pemberian sarapan sereal sebagai sumber asupan seng dengan rasio molar fitat:seng sekitar 2 sampai 43. Jika hasil perhitungan rasio molar fitat:seng $>15$ maka asupan fitat dikurangi dan asupan seng ditingkatkan karena pada kondisi ini fitat lebih dominan, tetapi apabila rasionya $<15$ maka dikatakan baik karena tidak memiliki pengaruh terhadap bioavailabilitas seng ${ }^{19}$.

Berdasarkan latar belakang atau penjelasan tersebut, perlu dilakukan penelitian gambaran kadar seng serum dan rasio molar fitat:seng pada anak usia sekolah dasar di Pesisir Kota Semarang.

\section{METODE PENELITIAN}

Penelitian ini dilakukan di SD Bangunsari, SDN Bandarharjo 01, dan SDN Bandarharjo 02, Kelurahan Bandarharjo, Kecamatan Semarang Utara, Kota Semarang, Jawa Tengah pada bulan April hingga Mei 2017. Penelitian ini termasuk dalam ruang lingkup keilmuan gizi masyarakat. Desain penelitian ini adalah cross-sectional. Subjek diambil sejumlah 50 sampel dengan non-probability sampling. Kriteria inklusi adalah anak berusia 9-12 tahun, tidak sedang mengonsumsi suplemen kalsium, besi dan tembaga, dan tidak mengalami diare berturut-turut/penyakit kronis/infeksi saat pengambilan darah selama waktu penelitian. Kriteria eksklusi adalah subjek mengundurkan diri dari penelitian dan meninggal dunia saat proses penelitian berlangsung. Setiap subjek terpilih diberikan informed consent sebagai tanda subjek setuju ikut serta dalam penelitian. Penelitian ini telah mendapat ethical clearance dengan No. 418/EC/FKRSDK/VII/2017 dari Komite Etik Penelitian Fakultas 
Kedokteran Universitas Diponegoro/RSUP Dr. Kariadi Semarang.

Variabel terikat pada penelitian ini adalah kadar seng serum yang diambil pada sampel darah subjek. Sampel darah subjek diambil oleh tenaga kesehatan yang terlatih melalui pembuluh darah vena sebanyak $3 \mathrm{cc}$. Kadar seng serum darah diukur dengan alat Atomic Absorption Spechtrophotometry (AAS) dalam satuan $\mu \mathrm{g} / \mathrm{dL}$ di Laboratorium GAKY Fakultas Kedokteran Universitas Diponegoro Semarang. Variabel bebas dalam penelitian ini adalah rasio molar fitat:seng yaitu nilai dari asupan fitat dalam miligram per massa molekuler fitat dibagi asupan seng dalam miligram per massa molekuler seng. Nilai asupan diperoleh dengan menggunakan instrumen 3x24 hours Food Recall dan 3xFood Record. Selanjutnya asupan makanan dikonversi dalam bentuk URT menjadi rerata gram per hari. Data diperoleh dari program komputer menggunakan data rata-rata asupan seng dan fitat per hari yang berasal dari instrumen $3 \times 24$ hours food recall dan food record dalam satuan miligram menjadi molar selanjutnya dirasiokan antara asupan fitat dan seng. Variabel perancu pada penelitian ini adalah asupan protein, kalsium, besi, dan tembaga.

Keterangan:

$$
\frac{\mathrm{mg} \text { fitat } / 660}{\mathrm{mg} \text { seng } / 65,4}
$$

- 660 = massa molekuler fitat

- 65,4 = massa molekuler seng
Sebelum dianalisis semua data diuji kenormalannya menggunakan Kolmogorov-Smirnov karena jumlah sampel $>30$. Analisis univariat data numerik kemudian disajikan dalam bentuk rata-rata dan standar deviasi. Setelah itu, dilakukan analisis bivariat antara variabel terikat dengan variabel bebas maupun variabel perancu menggunakan uji Pearson's apabila data normal, dan uji Spearman apabila data tidak normal. Hubungan antara kadar seng serum dengan jenis kelamin diuji dengan uji Continuity Correction sebagai uji alternatif chisquare karena jenis kelamin merupakan kategorik dan sampel lebih dari 40.

\section{HASIL PENELITIAN}

Subjek penelitian terdiri dari 30 subjek laki-laki dan 20 subjek perempuan. Karakteristik status gizi berdasarkan TB/U dengan kategori pendek sebanyak 18\%. Berdasarkan IMT/U dengan kategori kurus sebanyak $12 \%$. Selanjutnya untuk kadar seng serum, sebesar $14 \%$ dari subjek keseluruhan memiliki kadar seng serum yang rendah dan tingkat rasio molar fitat:seng sebesar $46 \%$ dari subjek keseluruhan yang memiliki tingkat absorpsi seng rendah. Berdasarkan gambaran kecukupan asupan gizi, untuk asupan seng, besi, kalsium dan tembaga, seluruh subjek pada penelitian ini berada pada kategori kurang (100\%). Selanjutnya untuk asupan protein, sebagian besar juga mengalami kekurangan asupan protein yaitu sebesar 68\% (tabel 1).

Tabel 1. Karakteristik status gizi, kadar seng serum, tingkat rasio molar fitat: seng, dan asupan

\begin{tabular}{|c|c|c|c|c|c|c|}
\hline \multirow{2}{*}{ Variabel } & \multicolumn{2}{|c|}{ Laki-laki } & \multicolumn{2}{|c|}{ Perempuan } & \multicolumn{2}{|c|}{ Total } \\
\hline & $\mathbf{N}$ & $\%$ & $\mathbf{n}$ & $\%$ & $\mathbf{n}$ & $\%$ \\
\hline \multicolumn{7}{|l|}{ Z-Score TB/U } \\
\hline Pendek & 5 & 10 & 4 & 8 & 9 & 18 \\
\hline Normal & 26 & 52 & 15 & 30 & 41 & 82 \\
\hline \multicolumn{7}{|l|}{ Z-Score IMT/U } \\
\hline Kurus & 4 & 8 & 2 & 4 & 6 & 12 \\
\hline Normal & 18 & 36 & 13 & 26 & 31 & 62 \\
\hline Gemuk & 9 & 18 & 4 & 8 & 13 & 26 \\
\hline \multicolumn{7}{|l|}{ Tingkat rasio molar fitat:seng } \\
\hline Tingkat absorpsi seng tinggi $(<5)$ & - & - & - & - & - & \\
\hline Tingkat absorpsi seng sedang (5-15) & 16 & 32 & 11 & 22 & 27 & 54 \\
\hline Tingkat absorpsi seng rendah $(>15)$ & 13 & 26 & 10 & 20 & 23 & 46 \\
\hline \multicolumn{7}{|l|}{ Kadar Seng Serum } \\
\hline Rendah & 5 & 10 & 2 & 4 & 7 & 14 \\
\hline Normal & 28 & 56 & 15 & 30 & 43 & 86 \\
\hline \multicolumn{7}{|l|}{ Asupan protein $(\mathrm{g})$} \\
\hline Kurang $(<90 \%)$ & 20 & 67 & 15 & 50 & 34 & 68,0 \\
\hline Cukup $(\geq 90 \%)$ & 10 & 33 & 5 & 17 & 15 & 30,0 \\
\hline \multicolumn{7}{|l|}{ Asupan seng (mg) } \\
\hline Kurang $(<90 \%)$ & 30 & 100 & 20 & 100 & 50 & 100,0 \\
\hline Cukup $(\geq 90 \%)$ & - & - & - & - & - & - \\
\hline \multicolumn{7}{|l|}{ Asupan besi (mg) } \\
\hline Kurang $(<90 \%)$ & 30 & 100 & 20 & 100 & 50 & 100,0 \\
\hline Cukup $(\geq 90 \%)$ & - & - & - & - & - & - \\
\hline Asupan kalsium (mg) & & & & & & \\
\hline
\end{tabular}




\begin{tabular}{lcccccc}
\hline Kurang $(<90 \%)$ & 30 & 100 & 20 & 100 & 50 & 100,0 \\
Cukup $(\geq 90 \%)$ & - & - & - & - & - & - \\
Asupan tembaga (mg) & & & & & & \\
Kurang $(<90 \%)$ & 30 & 100 & 20 & 100 & 50 & 100,0 \\
Cukup $(\geq 90 \%)$ & - & - & - & - & - & - \\
\hline
\end{tabular}

Berdasarkan tabel 2, rerata nilai simpangan baku TB/U, IMT/U, kadar seng serum, dan rasio molar fitat:seng termasuk dalam kategori normal. Asupan protein, besi, kalsium, seng, dan tembaga termasuk dalam kategori kurang. Kemudian untuk hasil uji korelasi menunjukkan tidak terdapat hubungan antara rasio molar fitat:seng dengan kadar seng serum. Hal yang sama juga terjadi pada asupan protein, seng, kalsium, besi, tembaga, fitat, IMT/U, dan TB/U yang tidak menunjukkan hubungan dengan kadar seng serum.

Tabel 2. Gambaran rerata dan hubungan kadar seng serum dengan Rasio Molar Fitat:Seng, Asupan protein, Seng, Kalsium, Besi, Tembaga, Fitat, IMT/U, dan TB/U

\begin{tabular}{|c|c|c|c|c|c|}
\hline \multirow{2}{*}{ Variabel } & \multicolumn{3}{|c|}{ Rerata \pm SD } & \multirow[b]{2}{*}{$r$} & \multirow[b]{2}{*}{$p$} \\
\hline & Laki-laki & Perempuan & Rata-rata & & \\
\hline Kadar Seng serum $(\mu \mathrm{g} / \mathrm{dl})$ & $92,20 \pm 22,45$ & $96,32 \pm 24,17$ & $93,85 \pm 22,99$ & & \\
\hline Z-Score TB/U $(\mathrm{cm})$ & $-1,18 \pm 0,80$ & $-1,42 \pm 0,74$ & $-1,28 \pm 0,78$ & $-0,039$ & $0,787^{\mathrm{b}}$ \\
\hline Z-Score IMT/U (kg/m²) & $-0,19 \pm 1,58$ & $-0,24 \pm 1,29$ & $-0,08 \pm 1,46$ & $-0,176$ & $0,221^{\mathrm{b}}$ \\
\hline Rasio molar fitat:seng & $15,03 \pm 3,39$ & $14,49 \pm 5,19$ & $14,48 \pm 4,23$ & $-0,102$ & $0,427^{\mathrm{b}}$ \\
\hline Asupan protein $(\mathrm{g})$ & $48,26 \pm 14,73$ & $44,98 \pm 12,02$ & $46,95 \pm 13,68$ & 0,068 & $0,685^{\mathrm{b}}$ \\
\hline Asupan Fitat (mg) & $801,11 \pm 279,18$ & $716,34 \pm 299,90$ & $767,20 \pm 287,68$ & $-0,002$ & $0,988^{a}$ \\
\hline Asupan besi (mg) & $5,59 \pm 2,10$ & $5,42 \pm 1,59$ & $5,52 \pm 1,89$ & $-0,028$ & $0,845^{\mathrm{b}}$ \\
\hline Asupan kalsium (mg) & $221,73 \pm 116,53$ & $236,80 \pm 102,35$ & $227,76 \pm 110,24$ & $-0,128$ & $0,354^{\mathrm{a}}$ \\
\hline Asupan seng (mg) & $5,44 \pm 1,98$ & $4,95 \pm 1,51$ & $5,58 \pm 3,06$ & 0,110 & $0,439^{\mathrm{b}}$ \\
\hline Asupan tembaga (mg) & $0,73 \pm 0,31$ & $0,61 \pm 0,21$ & $0,68 \pm 0,31$ & $-0,053$ & $0,719^{\mathrm{a}}$ \\
\hline Jenis Kelamin & & & & & $0,506^{\mathrm{c}}$ \\
\hline
\end{tabular}

${ }^{\mathrm{a} U j i}$ Rank-Spearman

${ }^{\mathrm{b} U j i}$ Pearson

${ }^{\mathrm{c}} \mathrm{Uji}$ Continuity Correction

\section{PEMBAHASAN}

Berdasarkan hasil skrining yang dilakukan pada anak Sekolah Dasar usia 9-12 tahun di Bandarharjo, untuk z-score TB/U didapatkan 18\% dari seluruh subjek berada dalam kategori pendek. Hasil ini menunjukkan bahwa terjadi penurunan persentase kategori pendek dari tahun 2015 sebesar $72 \%$ menjadi $18 \%$ pada tahun $2017^{20}$. Subjek yang memiliki kadar seng serum rendah (defisiensi seng) sebanyak 7 orang dan hanya 1 yang memiliki kategori pendek. Hal ini karena selain faktor z-score TB/U, defisiensi seng juga dipengaruhi faktor lain seperti asupan. Kategori pendek atau stunting pada usia sekolah, mengakibatkan anak cenderung sulit mencapai potensi pertumbuhan dan perkembangan yang optimal secara fisik maupun psikomotorik ketika dewasa nantinya yang berkaitan erat dengan kemunduran kecerdasan dan produktivitas ${ }^{21}$.

Hasil pengukuran dari z-score IMT/U pada penelitian ini adalah subjek berada pada kategori kurus sebesar $12 \%$ dan normal sebesar $62 \%$. Kategori kurus dan normal pada penelitian ini adalah untuk mengetahui tingkat defisiensi seng pada subjek karena anak yang mengalami defisiensi seng dapat beresiko malnutrisi, dimana keberadaan seng di dalam tubuh diperlukan untuk pertambahan berat jaringan otot dan adiposa yang baru ${ }^{22}$. Selain itu, penelitian di Rumania juga menunjukkan bahwa kadar seng berkorelasi secara positif terhadap status gizi batita ${ }^{23}$. Pada penelitian ini lebih besar persentase $z$-score IMT/U yang berada pada kategori normal dan sejalan dengan persentase kadar seng serum yang juga sebagian besar berada pada kategori normal. Sedangkan seluruh subjek yang kadar seng serumnya rendah tidak ada yang berada pada kategori kurus.

Selain dilihat keterkaitan kadar seng serum dengan hasil skrining, hal utama yang dilihat adalah keterkaitan hasil kadar seng serum dengan nilai rasio molar fitat:seng. Hasil kadar seng serum berada pada kategori rendah sebesar $14 \%$ dan nilai rasio molar fitat:seng memiliki tingkat absorpsi seng yang rendah sebesar $46 \%$. Berdasarkan uji statistik antara kedua variabel tersebut, menghasilkan $p$ value $>0,05$ yang menunjukkan tidak terdapat hubungan yang signifikan antara kadar seng serum dengan rasio molar fitat:seng. Jika dilihat dari pengelompokkan jenis kelamin, hasil rasio molar fitat:seng pada lakilaki termasuk kategori tingkat absorpsi seng rendah, sedangkan pada perempuan termasuk tingkat absorpsi seng sedang, tidak ada yang berada pada tingkat absorpsi tinggi. Hal ini karena pada laki-laki berisiko terjadi defisiensi seng dua kali lebih besar 
dibandingkan dengan perempuan ${ }^{24}$. Kemudian dengan sebanyak $14 \%$ subjek yang memiliki kadar seng serum rendah, menunjukkan angka yang hampir mendekati $20 \%$, karena jika sudah melebihi $20 \%$ maka dikatakan sebagai permasalahan kesehatan yang serius ${ }^{25}$. Defisiensi seng merupakan salah satu dari 10 faktor terbesar yang berkontribusi terhadap terjadinya angka kematian yang tinggi akibat infeksi di negara-negara berkembang ${ }^{6}$.

Persentase dari kadar seng serum yang rendah sebesar $14 \%$ tersebut disebabkan oleh cukup banyaknya subjek yang memiliki tingkat absorpsi rendah, karena dalam penelitian ini jika dilihat berbagai pilihan jenis makanan pada anak usia 9-12 tahun, mereka gemar mengonsumsi makanan yang mengandung fitat seperti kacang, padi dan tepung sehingga tidak ada hasil rasio molar fitat:seng yang berada pada tingkat absorpsi tinggi. Penelitian yang dilakukan di Korea pada wanita muda dan lanjut usia menunjukkan bahwa fitat mempengaruhi jumlah seng yang diserap dari dalam usus ${ }^{26}$. Analisis seng yang dilakukan di San Francisco pada pria dengan usia 2035 tahun menunjukkan bahwa berkurangnya kadar seng serum hanya dapat digambarkan melalui perubahan asupan, ekskresi, dan absorpsi seng dalam jumlah yang besar dan waktu yang lama ${ }^{27}$. Hal tersebut dijelaskan melalui proses kinetik seng di dalam tubuh mulai dari penyerapan hingga ekskresi $^{27,28}$.

Variabel lain adalah dari asupan zat gizi lain seperti protein, besi, kalsium, dan tembaga yang dalam penelitian ini tidak menunjukkan hubungan yang signifikan terhadap kadar seng serum. Namun, asupan protein memiliki hubungan positif yang lemah dan asupan kalsium, besi, serta tembaga memiliki hubungan negatif yang lemah terhadap kadar seng plasma.

Asupan protein berperan dalam meningkatkan absorpsi seng. Hasil penelitian menunjukkan bahwa rerata asupan protein subjek termasuk dalam kategori defisit ringan yaitu sebesar 46,95 g/hari. Sedangkan jika dikelompokkan berdasarkan jenis kelamin, rerata subjek laki-laki berada pada kategori normal, pada subjek perempuan termasuk kategori defisit ringan. Data ini menunjukkan bahwa rerata asupan protein yang berada pada kategori defisit ringan mempengaruhi kecepatan absorpsi seng karena terdapat $14 \%$ mengalami defisiensi seng, dimana pada penelitian ini asupan seng termasuk dalam kategori defisit berat. Asupan protein mempengaruhi penyerapan seng di dalam usus sebagai salah satu komponen asupan yang mempengaruhi kecepatan dan status dari seng. Pada hewan percobaan, ketika mengonsumsi protein cukup maka akan berpengaruh pada pertumbuhan ${ }^{13}$. Namun, apabila mengonsumsi protein dalam jumlah sedikit
$(7,5 \%)$ selama empat minggu dan juga rendah mengonsumsi seng (1-3 mg/kg), maka tidak terdapat pertambahan berat badan, dan terjadi ketidaknormalan dari tembaga, besi dan seng di hati ${ }^{29}$. Absorbsi seng yang rendah dapat terlihat dari rendahnya asupan protein karena hal ini berkaitan dengan rendahnya availabilitas dari pemecahan protein yang mendukung pengurangan seng dari lumen intestinal. Pada percobaan melalui tikus, jika asupan protein pada tikus tidak cukup, tikus tersebut sulit untuk mencapai kecukupan seng. Selanjutnya, terdapat perbedaan yang signifikan pada pertumbuhan tikus yang mengonsumsi putih telur yang rendah (15\%) dan tinggi (30\%) dengan absorbsi asupan seng ${ }^{29}$. Protein juga berperan sebagai karier pada proses absorpsi seng ke dalam enterosit bernama Zrt- dan Irt- like Protein (ZIP) yang menjadi transporter seng utama di sepanjang membran enterosit. Selain sebagai karier, penyusun protein yaitu asam amino, berperan sebagai ligan untuk seng yang membantu meningkatkan asborpsi seng dan mempertahankan solubilitas seng di saluran pencernaan. Asam amino yang berperan yaitu histidin, sistein, lisin dan glisin ${ }^{30}$.

Asupan kalsium, besi, dan tembaga berperan dalam menghambat absorpsi seng. Pemenuhan rerata asupan kalsium pada subjek penelitian ini sebesar $227,76 \mathrm{mg} /$ hari yang termasuk dalam kategori defisit berat. Hubungan antara kalsium dan kadar seng serum tidak berhubungan karena kalsium dapat menghambat absorpsi seng hanya ketika terdapat fitat pada asupan yang dikonsumsi ${ }^{15}$. Pada penelitian ini, subjek yang mengalami defisiensi seng juga mengonsumsi fitat sehingga terjadi interkasi antara kalsium, fitat, dan seng. Hal ini karena kalsium cenderung untuk membentuk kompleks dengan fitat sehingga seng tidak dapat diserap dan menghambat absorpsi seng ${ }^{31}$.

Asupan besi pada subjek penelitian ini sebesar 5,52 mg/hari yang termasuk dalam kategori defisit berat. Keadaan defisit berat ini dapat mempengaruhi penyerapan seng karena beberapa dari subjek yang mengalami defisiensi seng, memiliki tingkat asupan besi $2 \mathrm{x}$ lebih banyak dari pada asupan seng. Asupan besi mempengaruhi penyerapan seng di dalam usus dengan bersifat sebagai kompetitor seng ketika jumlah besi lebih besar daripada jumlah seng ${ }^{16}$.

Selanjutnya, rerata asupan tembaga pada penelitian ini sebesar $0,68 \mathrm{mg} / \mathrm{hari}$ yang juga termasuk kategori defisit berat. Keberadaan asupan tembaga yang sedikit ini tidak terlalu mengganggu absorpsi seng karena tembaga menjadi inhibitor yang lemah $^{32}$. 


\section{KETERBATASAN PENELITIAN}

Keterbatasan pada penelitian terkait rasio molar fitat:seng dengan kadar seng serum ini adalah tidak dapat menganalisis zat-zat lain yang berkaitan dengan asupan seng seperti polifenol dan asam oksalat karena keterbatasan software yang digunakan. Selain itu, dalam penelitian ini belum dihitung rasio molar fitat dengan mineral lainnya untuk mengetahui apakah ada kemungkinan pengaruh terhadap kadar seng serum.

\section{SIMPULAN}

Persentase dari hasil kadar seng serum subjek yang mengalami defisiensi seng sebesar $14 \%$ dan subjek yang memiliki tingkat absorpsi seng rendah sebesar 46\%. Tidak terdapat hubungan yang signifikan antara rasio molar fitat:seng dengan kadar seng serum.

\section{SARAN}

Apabila ingin melakukan pengembangan dalam penelitian ini, sebaiknya dilakukan analisis zatzat lain seperti polifenol dan asam oksalat dengan mencari software untuk mengujinya serta dilakukan perhitungan rasio molar fitat dengan zat gizi lainnya agar dapat diketahui keterkaitannya dengan kadar seng serum. Selain itu, pemantauan asupan dapat dilakukan dalam jangka waktu yang lebih lama karena akan mempengaruhi validasi data dan kekuatan pengikatan fitat terhadap seng serta membandingkan dengan metode pengambilan data asupan lain.

\section{UCAPAN TERIMAKASIH}

Puji syukur penulis haturkan ke hadirat Allah SWT atas segala ridho dan rahmat yang telah diberikan kepada penulis. Terimakasih penulis sampaikan kepada pembimbing, seluruh responden dan enumerator yang terlibat dalam penelitian atas kerjasama selama penelitian ini berlangsung serta semua pihak yang telah memberikan dukungan selama ini.

\section{DAFTAR PUSTAKA}

1. Anindita P. Hubungan tingkat pendidikan ibu, pendapatan keluarga, kecukupan protein \& seng dengan stunting (pendek) pada balita usia 6-35 bulan di kecamatan Tembalang kota semarang. Jurnal Kesehatan Masyarakat FKM UNDIP. 2010; 3 (2): 311.

2. Black MM. Zinc deficiency and cognitive development. University of Maryland School of Medicine. USA: Woodhead Publishing Limited; 2011. p. 79.

3. Gibney JM. Gizi kesehatan masyarakat. Jakarta: Buku kedokteran ECG;2009.
4. Rahman SN, Sirajuddin S, Alharini S. Hubungan pola konsumsi pangan sumber seng dengan status seng anak sekolah dasar. Program Studi Ilmu Gizi, Fakultas Kesehatan Masyarakat, Universitas Hasanuddin.

5. Stone RE, Ndjebayi AO, Nankap M, Killilea DW, Brown KH. Stunting prevalence, plasma zinc concentrations, and dietary zinc intakes in a nationally representative sample suggest a high risk of zinc deficiency among women and young children in cameroon. J. Nutr. 2014;144: 382-391.

6. Fesharakinia A, Zarban A, Sharifzadeh R. Prevalence of zinc deficiency in elementary school children of south khorasan province (East Iran). Original Article Iran Journal Pediatrics. 2009;19(3):249-254

7. Kementerian Kesehatan Republik Indonesia. Riset Kesehatan Dasar 2013. Badan Penelitian dan Pengembangan Kesehatan, Kementerian Kesehatan RI 2013.

8. Suryaningtyas R, Panunggal B. Hubungan Asupan Fitat dengan Status Seng Serum pada Anak Sekolah Dasar [Skripsi]. Semarang: Universitas Diponegoro;2015.

9. Hot $\mathrm{C} \&$ Brown KH. Contents International Zinc Nutrition Consultative Group (IZiNCG) Technical Document \# 1 Assessment of the Risk of Zinc Deficiency in Populations and Options for Its Control. International Nutrition Foundation 2004;25:S94-S203.

10. Tandukar KP, Jacelon CS, Johnson ERB, Palmer PH, Poudel KC. Serum zinc concentrations and depression in persons with Human Immunodeficiency Virus infection: The positive living with HIV(POLH) study. Psychiatry Research. 2016;241:340-346

11. Setijowati N. Hubungan kadar seng serum dengan tinggi badan anak sekolah dasar penderita gaky. Jurnal Kedokteran Brawijaya. 2005;21(1).

12. Pryjambodo M. Hubungan antara kadar seng ( $\mathrm{Zn})$ serum dengan skor tuberkulosis paru anak [Tesis]. Semarang: Universitas Diponegoro;2008.

13. Megias C, Pedroche J, Yust MM, Giron-Calle J, Alaiz M, Millan F, Viogue J. Affinity purification of copper-chelating peptides from sunflower protein hydrolysates. Journal of Agricultural and Food Chemistry. 2007a; 55(16): 6509-6514.

14. Sathe SK, Reddy NR. Food Phytates. Boca Raton: CRC Press;2001.

15. Lonnerdal B. Dietary factors influencing zinc absorption. J.Nutr. 2000;130:1378S-1383S.

16. Solomons NW. Competitive interaction of iron and zinc in the diet: consequences for human nutrition. $\mathrm{J}$ Nutr. 1986;116:927-935.

17. Badan Pusat Statistik. Rata-Rata Konsumsi per Kapita Seminggu Beberapa Macam Bahan Makanan Penting, 2007-2015. https://www.bps.go.id/linkTabelStatis/view/id/950 (diakses tanggal 11 Agustus 2017)

18. Oxtoby DW, Gillis HP, Nachtrieb NH. Principles of Modern Chemistry. Silvester Lemeda Simarmata. 4th ed jilid 1. Harcourt Inc; 1999. 
19. Lazarte CE, Carlsson NG, Almgren A, Sandberg AS, Granfeldt Y. Phytate, zinc, iron and calcium content of common Bolivian food, and implications for mineral bioavailability. Journal of Food Composition and Analysis. 2015;39:111-119.

20. Anggraheni N, Pramono A. Gambaran kadar serum seng $(\mathrm{Zn})$ dengan $\mathrm{z}$-score TB/U pada anak usia 9-12 tahun [Skripsi]. Semarang: Universitas Diponegoro;2015

21. Engle-Stone, R, Ndjebayi AO, Nankap M, Killilea DW, \& Brown KH. Stunting Prevalence, Plasma Zinc Concentrations, And Dietary Zinc Intakes In A Nationally Representative Sample Suggest A High Risk Of Zinc Deficiency Among Women And Young Children In Cameroon. J Nutr.2012;144:382-39.

22. Ross AC, Caballero B, Cousins RJ, Tucker KL, Ziegler TR. Modern nutrition in health disease: edisi ke-11. Philadelphia: Lippincott Williams \& Wilkins; 2014.

23. Negrut N, Mircea N. Relationship between plasma level of zinc and growth of children under the age of three. Journal of Ecotoxicology. 2013;12(B):291-9.

24. Thurlow RA, et al.Risk of zinc, iodine and other micronutrient deficiencies among school children in North East Thailand. European Journal of Clinical Nutrition. 2006;60:623-632.

25. Prawirohartono EP, Lestari SK, Nurani N, Sitaresmi MN. Difference In Nutrient Biomarkers Concentratio By Habitual Intake Of Milk Among Preschool Children In An Urban Area Of Indonesia. Journal of Human Nutrition and Food Science. 2015;3(1):1055.

26. Kim J, Paik HY, Joung H, Woodhouse LR, Li S, king JC. Effect of dietary phytate on zinc homeostasis in young and elderly korean women. American College of Nutritio. 2007;26:1-9.

27. King JC, Shames DM, Lowe NM, Woodhouse LR, Sutherland B, Abrams SA, et al. Effect of acutte zinc depletion on zinc homeostasis and plasma zinc kinetics in men. Am J Clin Nutr. 2001;74:116-24.

28. Kim J, Paik HY, Joung H, R L, Woodhouse, King JC. Plasma zinc but not the exchangeable zinc pool size differs between young and older korean women. Biol Trace Elem Res. 2011;142:130-6.

29. Megias C, Pedroche J, Yust MM, Giron-Calle J, Alaiz M, Millan F, Viogue J. Affinity purification of copper-chelating peptides from sunflower protein hydrolysates. Journal of Agricultural and Food Chemistry. 2007a; 55(16): 6509-6514.

30. Sareen SG, Jack LS, James LG. Advanced nutrition and human metabolism. $5^{\text {th }}$ ed. Canada: Wardsword; 2009. p.6.

31. Maggini S, Beveridge S, Suter M. A combination of High-dose Vitamin C Plus Zinc for the Common Cold. The Journal of International Medical Research. 2012;40(1):28-42.

32. Segawa S, Shibamoto M, Ogawa M, Miyake S, Mizamoto K, Ohishi A, et al. The Effect of Divalent Metal Cations on Zinc Uptake by Mouse Zrt/Irt Like Protein 1 (ZIP1). Life Sciences. 2014;113(2014):404. 